\title{
ANALISIS DAN PERANCANGAN SISTEM INFORMASI PENGGAJIAN KARYAWAN BERBASIS WEB PADA PT. BATAM BINTAN TELEKOMUNIKASI LAGOI
}

\author{
Nanny Raras Setyoningrum ${ }^{1}$, Danil Syah Arihardjo ${ }^{2}$ \\ ${ }^{1,2}$ Sistem Informasi, STT Indonesia Tanjungpinang \\ email: nannysetyoningrum141@gmail.com*
}

\begin{abstract}
Abstrak: Sistem penggajian merupakan hal penting dalam sebuah perusahaan. Gaji adalah salah satu hal penting yang mendorong kinerja pegawai agar perusahaan tetap berjalan baik. PT. Batam Bintan Telekomunikasi Operasi Pelayanan Lagoi dalam perhitungan gaji masih secara manual hanya menggunakan MS.Excel dan slip gaji masih secara manual berupa slip gaji yang akan diserahkan kepada pegawai. Hal ini membuat pekerjaan di bagian keuangan menjadi lambat, serta pegawai tidak bisa mendapatkan informasi pendapatan lembur. Tujuan dari penelitian ini merancang sistem informasi untuk mempermudah kinerja pengelolaan gaji. Dengan analisa SWOT, ditemukan faktor-faktor yang menjadi penyebab masalah pada sistem penggajian yang sedang berjalan pada PT. Batam Bintan Telekomunikasi Operasi Pelayanan Lagoi, dan ditemukan solusi untuk memecahkan atau meminimalisir masalah sistem penggajian saat ini. Metode dalam penelitian ini terbagi dalam dua tahapan yaitu metode pengumpulan data dengan observasi dan wawancara serta metode pengembangan perangkat lunak menggunakan model Waterfall. Sistem Informasi penggajian berbasis website dibuat dengan memanfaatkan Framework Laravel menggunakan bahasa pemrograman PHP, dan MySQL sebagai basis datanya. Dengan sistem penggajian berbasis web dapat membantu penghitungan gaji secara otomatis dan sistematis, juga cepat dan akurat. Dengan demikian, kinerja pegawai menjadi lebih baik dan perusahaan pun mendapatkan manfaatnya juga.
\end{abstract}

Kata Kunci : penggajian, Laravel, PHP, MySQL

\begin{abstract}
The payroll system is an important thing in a company. Salary is one of the important things that encourages employee performance so that the company continues to run well. PT. Batam Bintan Telecommunications Lagoi Service Operations in the calculation of salaries still manually only use MS.Excel and pay slips are still manually in the form of a salary slip to be submitted to employees. This makes work in the finance department slow, and employees cannot get information about overtime income. The purpose of this study is to design an information system to facilitate the performance of salary management. With a SWOT analysis, it was found that the factors that cause problems in the current payroll system at PT. Batam Bintan Telecommunications Lagoi Service Operations, and solutions were found to solve or minimize problems with the current payroll system. The method in this research is divided into two stages, namely the data interview method with observation and interviews and the software development method using the Waterfall model. Website-based payroll information system is created using the Laravel Framework using the PHP programming language, and MySQL as its database. With a web-based payroll system can help calculate salaries automatically and systematically, as well as quickly and accurately. Thus, employee performance is better and the company gets the benefits too.
\end{abstract}

Keywords : payroll, Laravel, PHP, MySQL

\section{PENDAHULUAN}

Masalah gaji atau imbalan kerja bagi karyawan merupakan hal yang sensitif dan berpengaruh langsung pada produktivitas kerja individu. Penerapan sistem penggajian yang tepat dapat memberikan kepuasan bagi pekerja maupun instansi, hal ini berpengaruh pada kegiatan operasional instansi, sehingga siklus penggajian pada instansi sangat penting.

PT. Batam Bintan Telekomunikasi yang selanjutnya disebut PT. BBT merupakan perusahaan swasta yang bergerak di bidang jasa telekomunikasi yang berkantor pusat di Batam. Seiring dengan berkembangnya, PT. BBT sudah memiliki kantor operasi pelayanan di pulau Bintan yaitu Kawasan Industri Lobam, Kawasan Wisata Lagoi dan Tanjungpinang, yang mana dalam pelaksanaan penggajian karyawan dilakukan dikantor pusat, yang saat ini masih menggunakan MS Excel, dimana perhitungan gaji karyawan masih menggunakan rumus excel dan data-data tersebut tidak disimpan ke dalam database sehingga dalam pencarian data gaji karyawan memakan waktu yang relatif lama karena datanya yang terpisah. Pencetakan slip gaji pun masih diketik ulang menggunakan Microsoft Word sehingga bila mencetak slip gaji diharuskan membuka laporan penggajian yang telah dibuat di Microsoft Excel. Hal ini kurang efektif dan efisien, karena bisa terjadi kesalahan dalam membuat slip gaji karyawan dan mengakibatkan sering terjadinya keterlambatan pelaporan gaji.

Permasalahan lain yang biasanya terjadi ketika bagian keuangan menyerahkannya slip gaji ke setiap karyawan, yang membutuhkan waktu lama karena penempatan karyawan yang berbeda lokasi kantor operasi pelayanan. Selain itu dalam pembuatan laporan penerimaan gaji, setiap bulannya bagian HRD harus merekap dan memisahkan data gaji karyawan tetap dan karyawan kontrak yang kemudian di input menjadi laporan gaji setiap bulannya, kemudian setiap karyawan tidak bisa memantau data informasi pendapatan lembur.

Sistem penggajian termasuk salah satu kegiatan administrasi instansi yang memiliki peranan penting bagi setiap pegawai dalam 
memenuhi kesejahteraan ekonomi dan sebagai faktor utama untuk memacu semangat kerja pegawai dalam meningkatkan produktifitas kerja. Dengan adanya sistem penggajian dapat membantu staf keuangan dan HRD dalam menyelesaikan pekerjaannya dan juga meminimalisir kesalahan dalam penghitungan sistem penggajian tersebut.

Menurut penelitian yang dilakukan oleh Johandri Iqbal (2019) dengan judul Web based payroll information system at PT. Mega Pratama Insurance bahwa sistem akuntansi gaji dan upah untuk kebanyakan perusahaan adalah suatu sistem dari prosedur dan catatan-catatan yang memberikan kemungkinan untuk menentukan dengan cepat dan tepat beberapa jumlah pendapatan kotor setiap pegawai, beberapa jumlah yang harus dikurangi dan pendapatan untuk berbagai pajak dan potongan lainnya dan beberapa saldo yang harus diberikan kepada karyawan.

\section{TINJAUAN PUSTAKA}

Menurut Elisabet Yunaeti Anggraeni (2017) sistem informasi adalah suatu sistem dalam suatu organisasi yang mempertemukan kebutuhan pengolahan transaksi harian yang mendukung fungsi operasi organisasi yang bersifat manajerial dengan kegiatan strategi dari suatu organisasi untuk dapat menyediakan kepada pihak luar tertentu dengan informasi yang diperlukan untuk pengambilan keputusan.

Penelitian Anita Bawaiqki ,dkk (2019) yang berjudul "Aplikasi Sistem Pengolahan Data Nilai Siswa Berbasis WEB Pada SMKN 1 Kota Tangerang" menyatakan bahwa perancangan sistem informasi adalah tahap awal pendekatan masalah pada sistem.

Tujuan perancangan sistem secara umum adalah untuk memberikan gambaran umum kepada pemakai (user) mengenai sistem informasi yang baru serta untuk memenuhi kebutuhan pemakai (user) dalam memperoleh dan mengolah informasi yang ada. Langkah pertama pada perancangan sistem adalah membagi sistem ke komponenkomponen yang lebih kecil yang dinamakan subsistem. Metode analisa dan perancangan sistem pada penelitian ini menggunakan metode yang dikenal dengan nama System Development Life Cycle (SDLC).

Teknik pengembangan sistem berbasis Object Oriented Programming $(O O P)$ sangat cocok menggunakan UML atau Unified Modeling Language. Menurut Senja Nilasari (2016), Unified Modeling Language selanjutnya disebut UML adalah sebuah teknik pengembangan sistem yang menggunakan bahasa grafis sebagai alat untuk pendokumentasian dan melakukan spesifikasi pada sistem.

Gaji menurut Senja Nilasari (2016) adalah pembayaran pada karyawan secara periodik. Jumlah gaji cenderung tetap dan bisa naik atau turun sesuai kebijakan perusahaan. Secara umum, jumlah gaji tersebut akan tetap selama beberapa periode sedangkan menurut Johandri Iqbal (2019) bahwa sistem akuntansi gaji dan upah untuk kebanyakan perusahaan adalah suatu sistem dari prosedur dan catatan-catatan yang memberikan kemungkinan untuk menentukan dengan cepat dan tepat beberapa jumlah pendapatan kotor setiap pegawai, beberapa jumlah yang harus dikurangi dan pendapatan untuk berbagai pajak dan potongan lainnya dan beberapa saldo yang harus diberikan kepada karyawan.

Bahasa pemrograman yang digunakan dalam pengembangan sistem penggajian berbasis web dalam penelitian ini adalah PHP dan sistem manajemen database MySQL. Menurut Supono, Vidiandry Putratama (2018) PHP (PHP Hypertext Preproccesor) adalah suatu bahasa pemrograman yang digunakan untuk menejermahkan baris kode program menjadi kode mesin yang dapat dimengerti oleh komputer yang bersifat server-side yang dapat ditambahkan ke dalam HTML. MySQL adalah sistem manajemen database SQL yang bersifat open source dan paling populer saat ini .Dengan menggunakan framework Laravel sebagai salah satu framework PHP terbaik yang dikembangkan oleh Taylor Otwell. Menurut Yudho Yudhanto dan Helmi Adi Prasetyo (2018), framework adalah kumpulan fungsi (libraries) sehingga seorang programmer tidak perlu lagi membuat fungsi-fungsi dari awal dan biasanya disebut kumpulan library.

\section{METODE}

Metode dalam penelitian ini terbagi dalam dua tahapan yaitu metode pengumpulan data dan metode pengembangan perangkat lunak. Dalam proses pengumpulan data menggunakan cara observasi, wawancara dan studi literatur. Observasi dilakukan dengan cara mendatangi objek penelitian secara langsung ke PT. Batam Bintan Telekomunikasi Kantor Operasi Pelayanan Lagoi untuk mengumpulkan data dan mendapatkan hal-hal yang diperlukan untuk proses penelitian. Wawancara dilakukan kepada para pengguna sistem untuk mengetahui kebutuhan dari masing-masing pengguna terhadap sistem informasi penggajian.

Metode pengembangan perangkat lunak yang digunakan dalam membangun website informasi ini menggunakan model Waterfall (Classic Life Cycle) yang menyarankan pengembangan perangkat lunak secara sistematik dan berurutan yang dimulai dari tingkatan sistem tertinggi dan berlanjut ke tahap analisis, desain, pengkodean, pengujian dan pemeliharaan. Kelebihan dari metode ini adalah terstruktur, dinamis, dan sequential. Metode Waterfall dapat dilihat pada gambar 1 yang ditulis oleh Janner Simarmata dari buku yang berjudul Rekayasa Perangkat Lunak. 


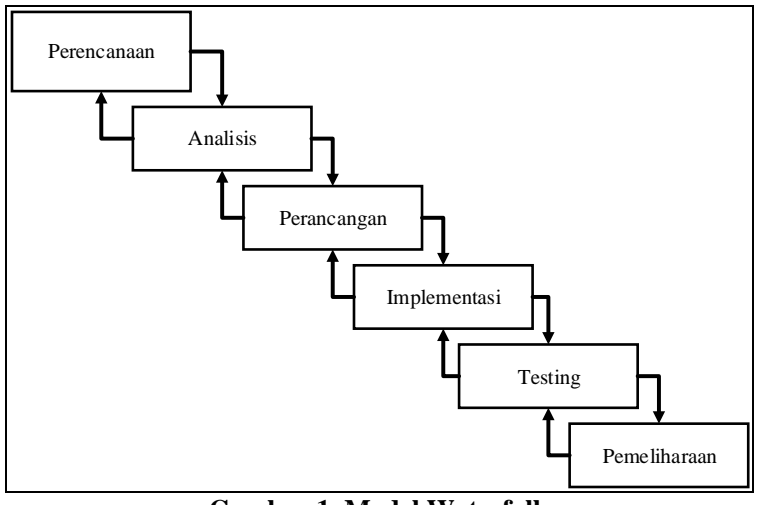

Gambar 1. Model Waterfall

\section{HASIL DAN PEMBAHASAN}

Perancangan sistem informasi pengajian ini diawali dengan melakukan analisis SWOT (Strengths, Weaknesses, Opportunities, Threats) yang digunakan untuk mengevaluasi kekuatan, kelemahan, peluang, dan ancaman dalam suatu sistem. Proses ini melibatkan penentuan tujuan yang spesifik dari spekulasi sistem dan mengidentifikasi faktor internal dan eksternal yang mendukung dan yang tidak mendukung dalam mencapai tujuan sistem.

Berikut analisis SWOT dalam perancangan sistem ini yang terdapat pada tabel 1 sebagai berikut :

Tabel 1. Analisis SWOT

\begin{tabular}{|c|c|c|}
\hline Internal & $\begin{array}{ll}\text { Strenght (Kekuatan) } \\
\text { 1. } \\
\text { Informasi lebih } \\
\text { cepat dan akurat. } \\
\text { 2. } \begin{array}{l}\text { Memudahkan } \\
\text { dalam menghitung } \\
\text { dan menyimpan }\end{array} \\
\text { gaji karyawan. } \\
\text { 3. } \quad \begin{array}{l}\text { Data karyawan } \\
\text { yang lebih lengkap. }\end{array} \\
\text { 4. } \begin{array}{l}\text { Memberikan } \\
\text { laporan penggajian }\end{array} \\
\text { karyawan yang } \\
\text { cepat, tepat dan } \\
\text { relevan. } \\
\text { Mempermudah } \\
\text { karyawan } \\
\text { mengetahui gaji. }\end{array}$ & 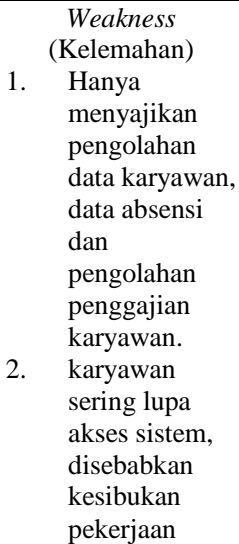 \\
\hline Eksternal & $\begin{array}{ll}\text { Opportunity (Peluang) } \\
\text { 1. } & \begin{array}{l}\text { PT. Batam Bintan } \\
\text { Telekomunikasi } \\
\text { menjadi lebih maju } \\
\text { dan berkembang. }\end{array} \\
\text { 2. } & \begin{array}{l}\text { Mempermudah } \\
\text { tugas bagian HRD, }\end{array} \\
\text { administrasi dalam } \\
\text { menghitung gaji } \\
\text { karyawan. } \\
\text { Perkembangan } \\
\text { zaman } \\
\text { memungkinkan } \\
\text { karyawan ingin } \\
\text { berkembang. }\end{array}$ & \begin{tabular}{ll}
\multicolumn{2}{l}{ Threats (Ancaman) } \\
1. & Terjadi \\
ketidak \\
percayaan \\
karyawan \\
terhadap data \\
absensi dan \\
penggjian \\
yang mereka \\
terima. \\
Karyawan \\
beranggapan \\
sistem ini \\
tidak penting \\
dan hanya \\
membingungk \\
an mereka.
\end{tabular} \\
\hline
\end{tabular}

Perancangan sistem penggajian ini menggunakan satu unit laptop dengan spesifikasi sebagai berikut :

1. Prosessor : Intel(R) Core i5-4300U CPU 1.90Ghz (4 CPUs), $2.5 \mathrm{GHz}$

2. Disk :256GB SSD

3. RAM : $8 \mathrm{~GB}$

4. VGA :2GB

5. Monitor : 14.0 " LED

6. Mouse dan Keyboard

Perangkat lunak (software) yang digunakan dalam perancangan Sistem Penggajian Karyawan Berbasis Web PT. Batam Bintan Telekomunikasi Operasi Pelayanan Lagoi adalah sebagai berikut :

1. Bahasa pemrograman yang digunakan : $P H P$, HTML, CSS, Javascript, Framework Laravel 5.8

2. Basis data yang digunakan sebagai penyimpanan data menggunakan MySQL.

3. Menggunakan text editor VSCode sebagai pengolahan source code dalam pembuatan aplikasi web penggajian.

4. XAMPP yang berfungsi sebagai Web Server.

5. Microsoft Windows 10 sebagai sistem operasi.

User yang akan menggunakan sistem informasi ini terdiri dari beberapa kategori user seperti terlihat pada tabel 2 sebagai berikut :

Tabel 2. Analisis pengguna

\begin{tabular}{|c|c|c|}
\hline No. & $\begin{array}{c}\text { Nama Kategori } \\
\text { User }\end{array}$ & Deskripsi Hak Akses \\
\hline 1 & Admin & $\begin{array}{l}\text { Memiliki hak akses penuh, dapat } \\
\text { melakukan seluruh proses yang } \\
\text { terdapat di sistem. }\end{array}$ \\
\hline 2 & HRD & $\begin{array}{c}\text { Proses pengolahan data karyawan } \\
\text { Proses pengolahan data absensi } \\
\text { Proses pengolahan data lembur } \\
\text { Proses pengolahan data gaji }\end{array}$ \\
\hline 3 & Karyawan & $\begin{array}{c}\text { Melihat data absensi } \\
\text { Melihat data lembur } \\
\text { Melihat data gaji. }\end{array}$ \\
\hline 4 & Manager & $\begin{array}{c}\text { Hanya bisa melihat laporan - } \\
\text { laporan }\end{array}$ \\
\hline
\end{tabular}

Use case diagram merupakan salah satu jenis diagram pada UML yang menggambarkan interaksi antara sistem dan aktor, use case diagram juga dapat mendeskripsikan tipe interaksi antara si pemakai sistem dengan sistemnya. Use case diagram sistem informasi penggajian karyawan berbasis web PT. Batam Bintan Telekomunikasi Operasi Pelayanan Lagoi digambarkan pada gambar 2 berikut : 


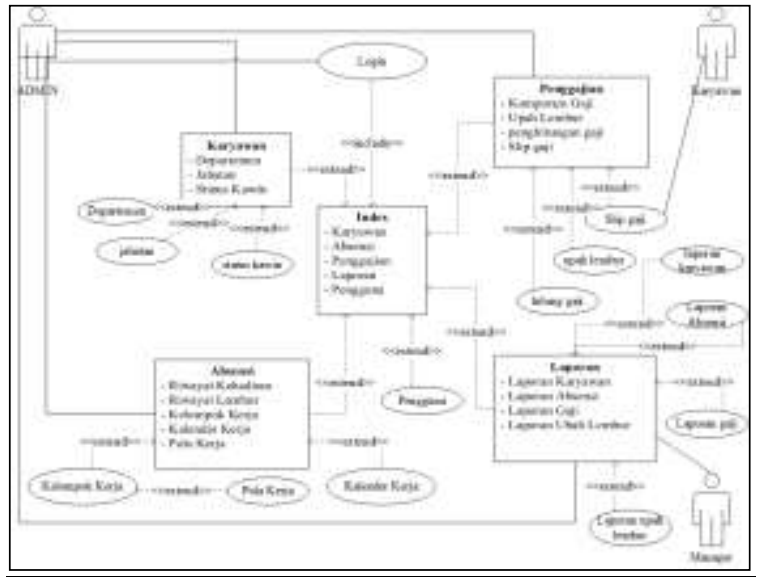

Gambar 2. Use case diagram sistem penggajian karyawan PT. Batam Bintan Telekomunikasi Operasi Pelayanan Lagoi

Activity Diagram merupakan salah satu jenis diagram pada UML yang dapat memodelkan prosesproses apa saja yang terjadi pada sistem. Activity diagram sistem informasi penggajian karyawan berbasis web PT. Batam Bintan Telekomunikasi Operasi Pelayanan Lagoi digambarkan pada gambar 3 berikut :

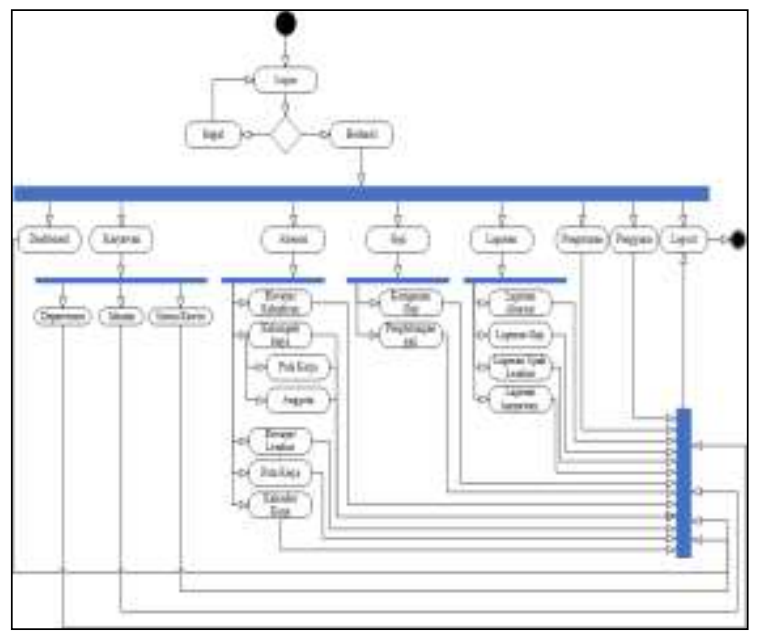

Gambar 3. Activity diagram sistem penggajian karyawan PT. Batam Bintan Telekomunikasi Operasi Pelayanan Lagoi

Sequence diagram menjelaskan interaksi objek yang berdasarkan urutan waktu, sequence diagram juga dapat menggambarkan urutan atau tahapan yang harus dilakukan untuk dapat menghasilkan sesuatu seperti pada use case diagram. Sequence diagram sistem informasi penggajian karyawan berbasis web PT. Batam Bintan Telekomunikasi Operasi Pelayanan Lagoi digambarkan pada gambar 4 berikut :

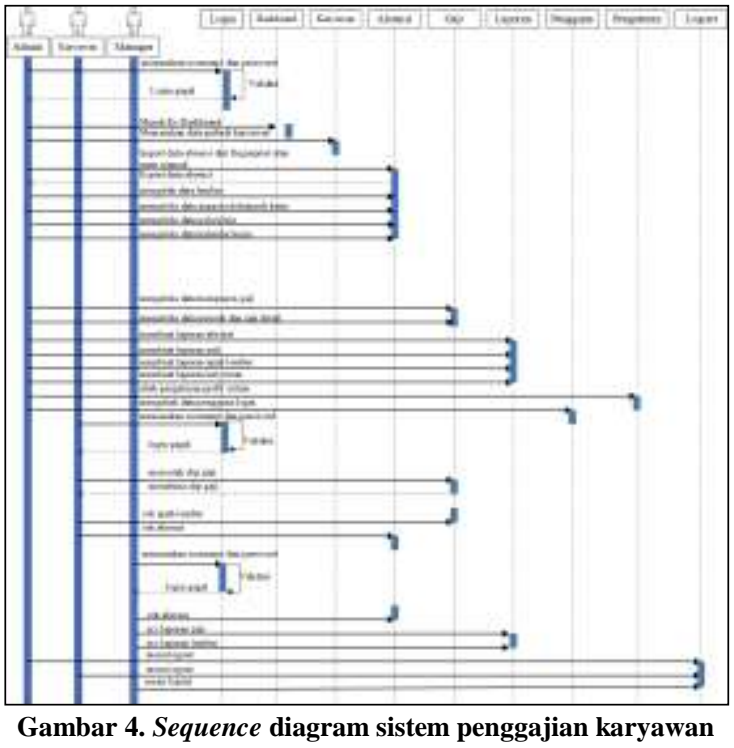

PT. Batam Bintan Telekomunikasi Operasi Pelayanan Lagoi

State machine diagram menggambarkan transisi maupun perubahan keadaan suatu objek pada sistem. State machine diagram sistem informasi penggajian karyawan berbasis web PT. Batam Bintan Telekomunikasi Operasi Pelayanan Lagoi digambarkan pada gambar 5 berikut :

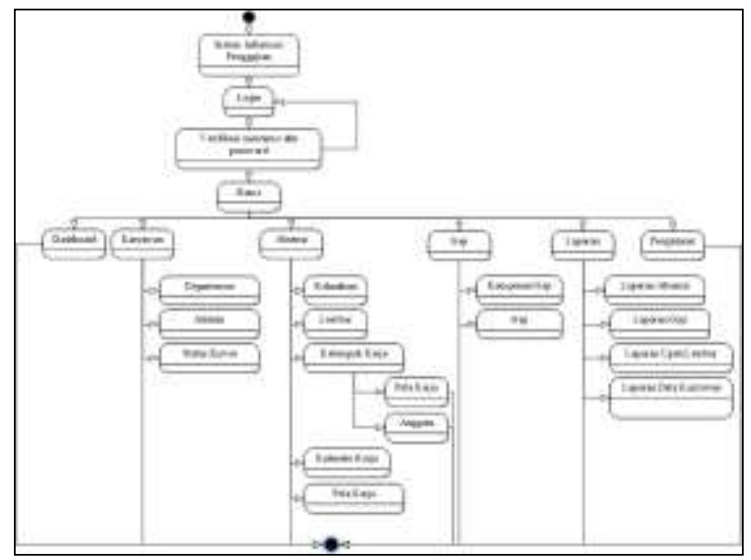

Gambar 5. State machine diagram sistem penggajian karyawan PT. Batam Bintan Telekomunikasi Operasi Pelayanan Lagoi

Class diagram digunakan untuk menampilkan kelas-kelas maupun paket-paket yang ada pada suatu sistem yang nantinya akan digunakan. Jadi diagram ini dapat memberikan sebuah gambaran mengenai sistem maupun relasirelasi yang terdapat pada sistem tersebut. Class diagram sistem informasi penggajian karyawan berbasis web PT. Batam Bintan Telekomunikasi Operasi Pelayanan Lagoi digambarkan pada gambar 6 berikut : 


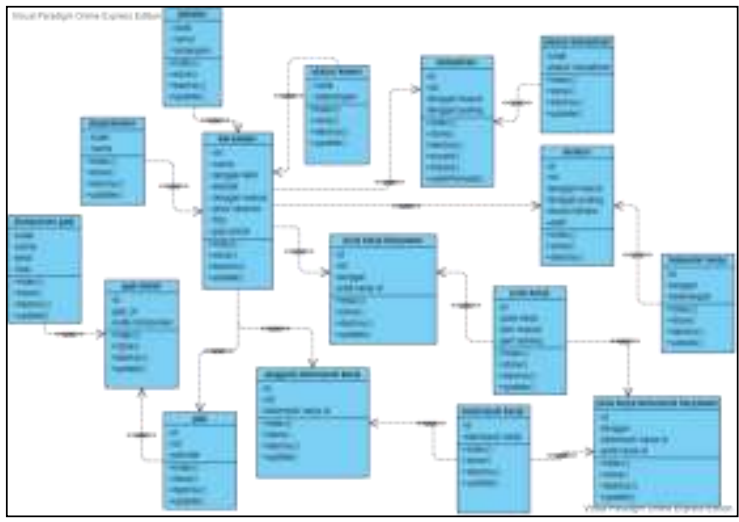

Gambar 6. Class Diagram sistem penggajian karyawan PT. Batam Bintan Telekomunikasi Operasi Pelayanan Lagoi

Dari hasil perancangan yang telah dibuat didapatkan hasil berupa implementasi tampilan sistem informasi penggajian karyawan PT. Batam Bintan Telekomunikasi Operasi Pelayanan Lagoi berbasis web sebagai berikut.

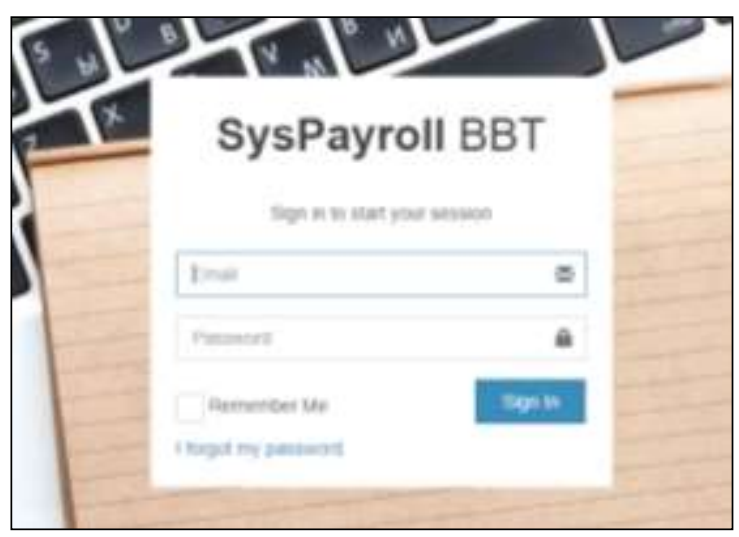

Gambar 7. Halaman login

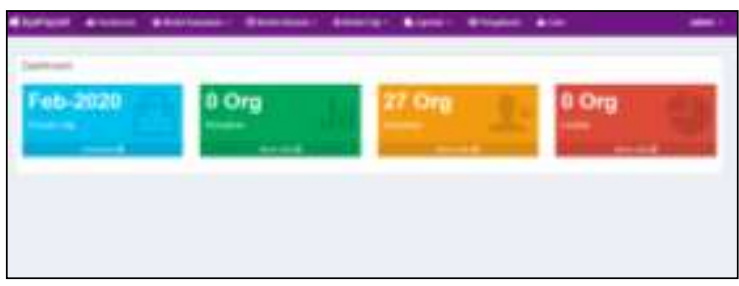

Gambar 8. Halaman dashboard

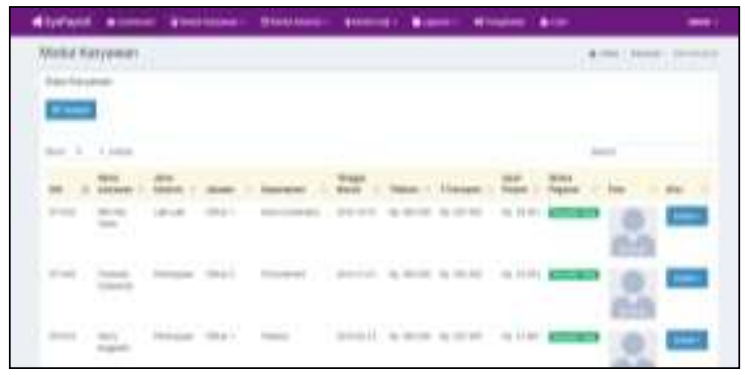

Gambar 9. Halaman karyawan

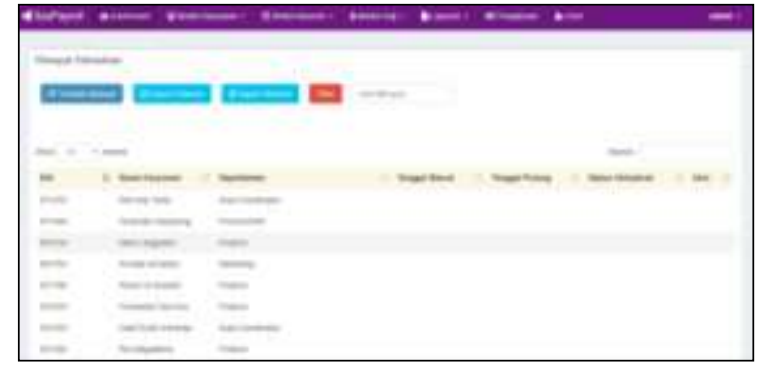

Gambar 10. Halaman riwayat kehadiran

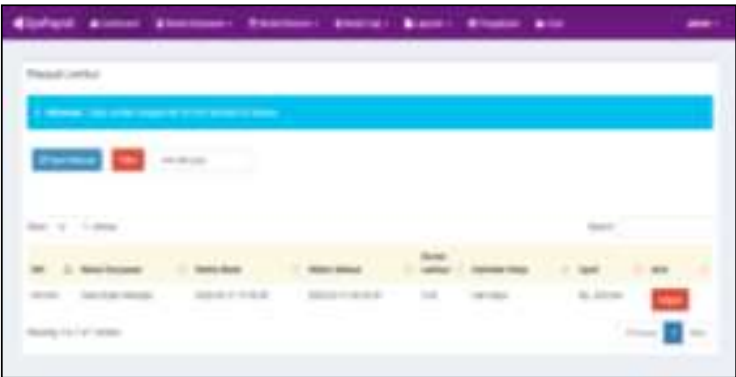

Gambar 11. Halaman riwayat lembur

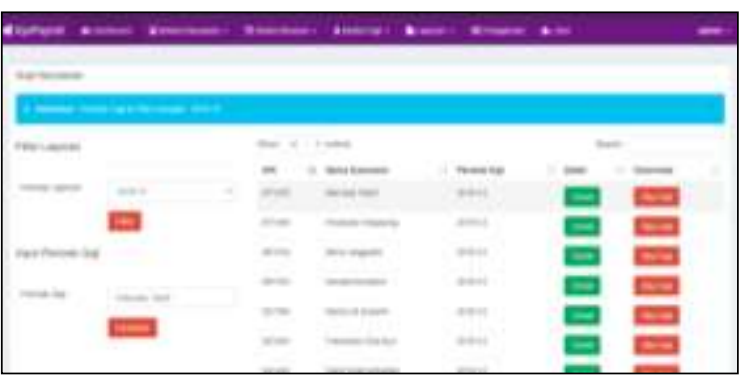

Gambar 12. Halaman gaji karyawan

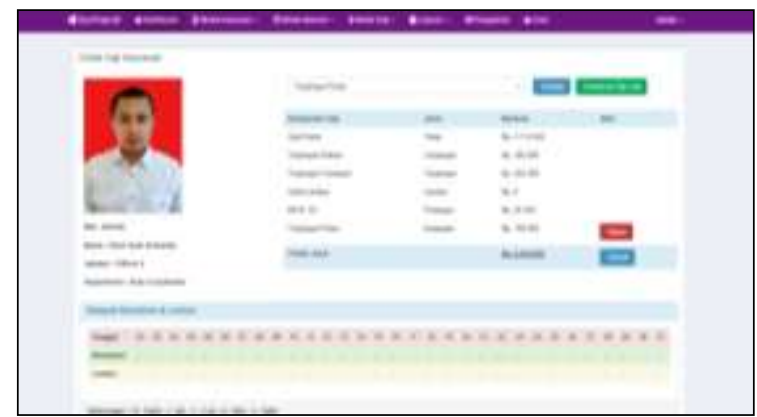

Gambar 13. Halaman gaji detail karyawan

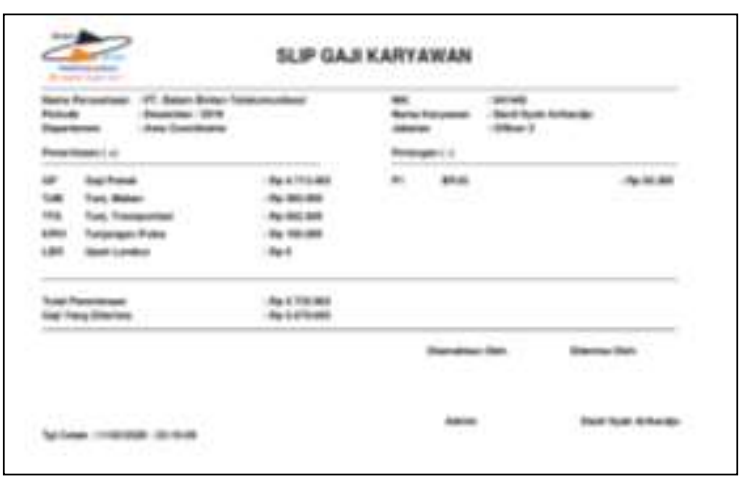

Gambar 14. Slip gaji karyawan 


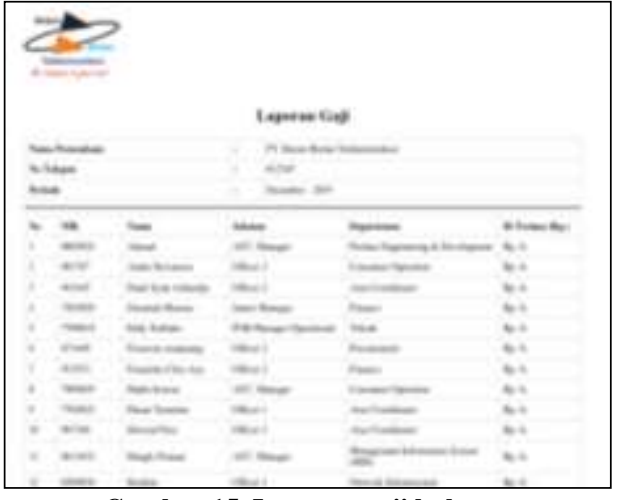

Gambar 15. Laporan gaji bulanan
[4] Nilasari, Senja. Andriansyah (Ed). 2016. Panduan Praktis Menyusun Sistem Penggajian \& Benefit. Jakarta: Raih Asa Sukses

[5] Putratama, Supono. Vidiandry. 2018. Pemrograman Web dengan Menggunakan PHP dan Framework Codeigniter. Yogyakarta: Deepublish

[6] Simarmata, Janner. 2010. Rekayasa Perangkat Lunak. Yogyakarta : Penerbit Andi.

[7] Yudhanto, Yudho. Helmi Adi Prasetyo. 2018. Panduan Mudah Belajar Framework Laravel. Jakarta: PT. Elex Media Komputindo

\section{KESIMPULAN DAN SARAN}

Berdasarkan hasil penelitian dan pengamatan sistem penggajian pada PT. Batam Bintan Telekomunikasi yang telah dilakukan, maka sistem yang dibangun untuk pengolahan lembur sudah dapat diolah secara online, sehingga memudahkan HRD dalam pengolahan lembur, dan karyawan dapat dengan mudah mendapatkan informasi data lembur secara cepat dan akurat. Pengolahan pola kerja sudah dapat diolah secara online, sehingga memudahkan HRD dalam pengolahan pola kerja dan karyawan dapat dengan mudah mendapatkan informasi secara tepat dan cepat. Pengolahan absensi sudah dapat diolah secara online, sehingga memudahkan bagian HRD dalam pengolahan absensi dan karyawan dapat dengan mudah mendapatkan informasi absensi secara tepat dan cepat. Sistem yang dibangun hanya dapat mengolah data karyawan, data pola kerja, data absensi, data lembur, proses penggajian sehingga menghasilkan laporan penggajian dan slip gaji karyawan secara periodik.

Sistem belum sepenuhnya sempurna dan memang masih jauh dari kata sempurna, segi keamanan maupun yang lainnya. Jadi, peneliti menyarankan untuk menyempurnakan hal-hal yang masih kurang sempurna sehingga sistem ini dapat menjadi sistem yang lebih sempurna. Agar sistem ini berjalan dengan baik, sebaiknya didukung oleh sumber daya yang memadai, baik dari segi sumber daya manusia (brainware), maupun peralatannya (hardware dan software). Sistem yang dibangun hendaknya dapat dikembangkan menjadi sebuah sistem berbasis mobile android ataupun IOS.

\section{DAFTAR PUSTAKA}

[1] Anggraeni, Elisabet Yunaeti. Rita Irviani. Erang Risanto (Ed). 2017. Pengantar Sistem Informasi. Yogyakarta: CV. Andi Offset

[2] Bawaiqki, Anita, dkk. 2019. Aplikasi Sistem Pengolahan Data Nilai Siswa Berbasis WEB Pada SMKN 1 Kota Tangerang, Jurnal Cerita, Vol.5 No.1.

[3] Iqbal, J. 2019. Web based payroll information system at PT. Mega Pratama Insurance. Journal Of Applied Accounting and Business, Vol 1 Edisi 1, 14-20 